\title{
MODEL PENGAWASAN PRESTASI KERJA PEGAWAI DI RUMAH SAKIT ARIFIN NU'MANG RAPPANG
}

\author{
${ }^{1)}$ Hendrika Utami, ${ }^{2)}$ Erfina, ${ }^{3)}$ Andi Astinah Adnan \\ Fakultas IImu Sosial dan IImu Politik Universitas Muhammadiyah Sidenreng Rappang \\ hendrikautami431620281b@gmail.com \\ erfinaerul85@gmail.com \\ andi.astinah.adnan@gmail.com
}

\begin{abstract}
Abstrak
Penelitian ini bertujuan untuk mengetahui model pengawasan di Rumah Sakit Arifin Nu'mang Rappang, untuk mengetahui pengaruh model pengawasan terhadap prestasi kerja pegawai di Rumah Sakit Arifin Nu'mang Rappang, dan untuk mengetahui faktor-faktor yang memengaruhi pengawasan di Rumah Sakit Arifin Nu'mang Rappang. Pendekatan metode penelitian yang akan digunakan dalam penelitian ini adalah pendekatan deskriptif kuantitatif. Populasi dalam penelitian ini adalah pegawai medis yang ada di Rumah Sakit Arifin Nu'mang Rappang yang terdiri dari 176 pegawai. Tekhnik sampel yang digunakan yaitu Purposif Sampling dengan menggunakan rumus Slovin sehingga menghasilkan 64 sampel. Tekhnik pengumpulan data dilakukan dalam penelitian ini adalah observasi, wawancara, kuesioner, dan studi kepustakaan. Data yang terkumpul kemudian diolah dan dianalisis dengan menggunakan tekhnik analisis deskriptif kuantitatif dengan bantuan statistik deskriptif dengan menggunakan SPSS 21.0 dan Skala Likert. Hasil penelitian menunjukkan bahwa model pengawasan di Rumah Sakit Arifin Nu'mang Rappang berada pada kategori jarang dengan persentase 53,95\%, pengaruh model pengawasan terhadap prestasi kerja pegawai di Rumah Sakit Arifin Nu'mang Rappang dengan persentase 55\% berpengaruh, faktorfaktor yang memengaruhi pengawasan di Rumah Sakit Arifin Nu'mang Rappang berada pada kategori jarang dengan persentase $51,36 \%$.
\end{abstract}

Kata Kunci : Model Pengawasan, Prestasi Kerja

\begin{abstract}
This study aims to determine the supervision model at Arifin Nu'mang Rappang Hospital, to determine the effect of the supervision model on employee work performance at Arifin Nu'mang Rappang Hospital, and to determine the factors that influence supervision at Arifin Nu'mang Rappang Hospital.The research method approach that will be used in this research is a quantitative descriptive approach. The population in this study were medical employees at Arifin Nu'mang Rappang Hospital wich consisted of 176 employees. The sample technique used is Purposive Sampling using the Slovin formula to produce 64 samples. Data collection techniques performed in this study were observation, interviews, questionnaires, and literature studies. The collected data is then processed and analyzed using quantitative descriptive analysis techniques with the help of descriptive statistics using SPSS 21.0 and Likert Scale. The results showed that the supervision model at Arifin Nu'mang Rappang Hospital was in the rare category with a percentage of $53.95 \%$, the influence of the supervisory model on the work performance of employees at Arifin Nu'mang Rappang Hospital with a percentage of 55\% influence, the factors affecting influencing supervision in Arifin Nu'mang Rappang Hospital is in the rare category with a percentage of $51,36 \%$.
\end{abstract}

Keywords: Supervision Model, Work Performance

PRAJA $\mid$ Volume 9 | Nomor $1 \mid$ Edisi Februari 2021 


\section{A. PENDAHULUAN}

Peraturan Pemerintah Nomor 46 Tahun 2011 tentang Penilaian Prestasi Kerja Pegawai Negeri Sipil PNS yang telah dikeluarkan oleh pemerintah yang bertujuannya untuk meningkatkan prestasi dan kinerja PNS. Peraturan Pemerintah ini adalah penyempurna dari PP Nomor 10 Tahun 1979 tentang Penilaian Pelaksanaan Pekerjaan PNS yang dianggap tidak sesuai lagi dengan perkembangan keadaan dan kebutuhan hukum.

Penilaian prestasi kerja merupakan sesuatu yang penting dilakukan dalam suatu instansi atau perusahaan dalam rangka pengembangan SDM. Kegiatan ini dapat memperbaiki keputusan manajer dan memberikan feedback kepada karyawan tentang kegiatan mereka" (Notoatmodjo, 1988). Penilaian kinerja (performance appraisal) memiliki peranan yang sangat penting dalam peningkatan motivasi di dalam lingkungan kerja. Karyawan memerlukan dan menginginkan umpan balik yang sesuai dengan prestasi mereka dan menyediakan kesempatan dalam penilaian untuk memberikan balikan kepada mereka. Ketika kinerja hasilnya tidak sesuai dengan yang telah dijadikan standar, maka penilaian memberikan kesempatan untuk melihat kemajuan karyawan dan kemudian menyusun kembali rencana peningkatan kinerja. Penilaian prestasi kerja adalah usaha dalam membandingkan prestasi kerja yang diharapkan darinya dengan prestasi aktual karyawan. (Montolalu \& Kaparang, 2015).

Penilaian prestasi kerja di Rumah Sakit Arifin Nu'mang Rappang diukur menurut Peraturan Pemerintah Nomor 46 Tahun 2011 tentang Penilaian Prestasi Kerja Pegawai Negeri Sipil PNS sebagaimana dimaksud dalam Pasal 12 meliputi aspek yaitu integritas, orientasi pelayanan, komitmen, kerjasama, dan disiplin. Rumah Sakit Arifin Nu'mang Rappang pada tanggal 28 Nopember 2019, terlihat data penilaian prestasi kerja yang menunjukkan bahwa terdapat masalah yang dinilai dari tingkat kedisiplinan pegawai di Rumah Sakit Arifin Nu'mang Rappang. Dari ke lima hal yang dilakukan menurut Mangkunegara dalam teori manajemen sumber daya manusia untuk pengembangan termasuk pengembangan prestasi kerja yang diukur dari tingkat kedisiplinan seperti permasalahan diatas salah satunya yaitu melakukan suatu
p-ISSN 2302-6960

e-ISSN 2716-165X

pengawasan. Sehingga penulis tertarik untuk merumuskan judul Model Pengawasan terhadap Prestasi Kerja Pegawai di Rumah Sakit Arifin Nu'mang Rappang dengan tujuan Untuk mengetahui model pengawasan di Rumah Sakit Arifin Nu'mang Rappang, Untuk mengetahui pengaruh model pengawasan terhadap prestasi kerja pegawai di Rumah Sakit Arifin Nu'mang Rappang, dan Untuk mengetahui faktor-faktor yang memengaruhi pengawasan di Rumah Sakit Arifin Nu'mang Rappang.

Smith (Soewartojo, 1995:131-132) menyatakan bahwa: "Controlling" juga diterjemahkan dengan arti pengendalian, pengertian yang dimaksud disini yaitu normanorma dan rencana-rencana yang mendasarkan manajerial pada maksud dan tujuannya, dimana norma-norma ini dapat berupa kuota, target dan pedoman pengukuran hasil kerja nyata terhadap yang ditetapkan. Pengawasan adalah kegiatankegiatan yang sistem tersebut diselenggarakan dalam kerangka normanorma yang telah ditetapkan atau dalam keadaan keseimbangan bahwa pengawasan memberikan deskripsi mengenai hal-hal yang dapat diterima, dipaksaka atau mungkin dipercaya, kemudian batas pengawasan (control limit) adalah tingkat nilai bawah atau atas suatu sistem dapat menerima sebagai batas toleransi dan tetap memberikan hasil yang cukup memuaskan. Dalam manajemen, pengawasan (controlling) adalah suatu kegiatan untuk membandingkan kegiatan operasional (actuating) di lapangan sudah sesuai atau tidak dengan rencana (planning) yang sudah ditetapkan dalam mencapai tujuan (goal) dari organisasi. Sehingga yang akan menjadi obyek dari kegiatan pengawasan merupakan yaitu mengenai kesalahan, cacat, penyimpangan, maupun hal-hal yang bersifat negatif seperti adanya kecurangan, pelanggaran dan korupsi. Pengawasan menurut George R. Terry adalah proses menentukan apa yang telah dilaksanakan maksudnya yaitu penilaian prestasi kerja dan apabila perlu, melakukan tindakan-tindakan yang memperbaiki sehingga hasil yang dikerjakan sesuai dengan rencana yang telah ditetapkan. (Glendoh, 2000).

Yosa (2010) dalam Arfianti (2011) yang dimaksud dengan pengawasan adalah suatu upaya yang sistematik untuk menetapkan kinerja standar pada peren-canaan untuk 
merancang sistem umpan balik informasi, untuk membandingkan kinerja aktual dengan standar yang telah ditentukan, untuk menetapkan apakah telah terjadi suatu penyimpangan, serta untuk mengambil tindakan perbaikan yang di-perlukan untuk menjamin bahwa sumber data organisasi atau pemerintahan telah digunakan seefektif dan seefisien mungkin guna mencapai tujuan organisasi atau pemerintah. (Ahmad, Mustanir, \& Ramadhan, 2018).

Merealisir tujuan utama tersebut, maka pengawasan pada taraf pertama bertujuan agar pelaksanaan pekerjaan sesuai dengan instruksi yang telah dikeluarkan, dan untuk mengetahui kelemahan- kelemahan serta kesulitan-kesulitan yang di hadapi dalam pelaksanaan rencana berdasarkan penemuan-penemuan tersebut dapat di ambil tindakan untuk memperbaikinya baik pada waktu itu ataupun waktu- waktu yang akan datang (Latman, lqbal, Al, \& Ahmad, n.d.). Adapun faktor yang memengaruhi pengawasan yang semakin diperlukan di setiap organisasi seperti yang dikemukakan oleh T. Hani Handoko

1. Perubahan Lingkungan Organisasi. Melalui fungsi pengawasan manajer mendeteksi perubahan yang berpengaruh pada barang maupun jasa organisasi, sehingga dapat menghadapi tentang memanfaatkan kesempatan yang diciptakan perubahan - perubahan yang terjadi.

2. Peningkatan Kompleksitas Organisasi. Semakin besar organisasi maka semakin memerlukan pengawasan yang lebih hatihati dan formal.

3. Kesalah-kesalahan. Sistem pengawasan yang memungkinkan manajer atau seorang pemimpin untuk menemukan kesalahan-kesalahan yang ada sebelum menjadi lebih buruk. 4. Kebutuhan Manajer untuk
Mendelegasikan Wewenang

Tanggung jawab atasan tidak berkurang bilamana manajer mendelegasikan wewenang kepada bawahannya. Salah satu cara manajer yang dapat menentukann bahwa bawahan telah melakukan tugastugas yang telah dilimpahkan kepadanya yaitu dengan cara pengimplementasian sistem pengawasan. (Baihaqi, 2016). Adapun model pengawasan selanjutnya dikemukakan oleh Hasibuan 2005 yaitu :
1. Kontrol internal merupakan pengawasan yang dilakukan oleh seorang atasan terhadap bawahannya. Hal ini mencakup sangat luas seperti pelaksanaan kerja, prosedur kerja, kedisiplinan karyawan dan lain-lain.

2. Kontrol eksternal adalah pengawasan yang dilakukan oleh pihak-pihak luar. Pengendalian ini dapat dilakukan dengan formal maupun informal, misalnya dengan pemeriksaan pembukuan dari kantor akuntan ataupun penilaian dari masyarakat.

3. Kontrol formal merupakan pengawasan yang dilakukan oleh pejabat resmi atau atau instansi yang bisa dilakukan dengan cara formal ataupun informal.

4. Kontrol informal merupakan penilaian yang dilberikan baik secara langsung maupun tidak langsung oleh masyarakat atau konsumen.

Kemajuan instansi atau organisasi tentunya didukung oleh kinerja karyawan atau pegawainya. Seseorang dapat dikatakan mempunyai kinerja yang baik, manakala mereka dapat melaksanakan pekerjaan dengan baik, artinya mencapai sasaran dengan atau menurut standar yang ditentukan dengan penilaian kinerja, dengan kata lain akan mendorong karyawan untuk bersaing memperoleh penghargaan, bonus atau dipromosikan kejabatan yang lebih baik.Prestasi kerja merupakan hal utama yang menjadi perhatian bagi perusahaan.(Kamaruddin Sellang, 2014)

Anwar Prabu Mangkunegara (2001:67) "Prestasi kerja merupakan hasil kerja secara kuantitas dan kualitas yang ingin dicapai seorang pegawai sesuai dengan tanggung jawabnya dalam melaksanakan tugas yang telah dibebankan kepadanya". Menurut T. Hani Handoko (2001;96) "Prestasi kerja merupakan hasil kerja yang dicapai seseorang dalam melaksanakan tugas yang dibebankan kepadanya". (Yuniastuti, 2011). Prestasi kerja adalah hasil kerja yang telah dicapai seseorang dari sikap atau tingkah laku dalam melakukan aktivitas kerjanya (Sutrisno, 2014:151). Menurut Hasibuan, (2010:94), prestasi kerja merupakan suatu hasil kerja yang telah dicapai oleh seorang karyawan dalam melaksanakan tugas-tugas yang dibebankan kepadanya yang didasarkan atas pengalaman, kesungguhan dan kecakapan serta waktu. (Widyawaty, 2015). Sutrisno (2014:152) mengemukakan 
beberapa indikator prestasi kerja sebagai berikut (Widyawaty, 2015):

1. Hasil kerja tingkat kuantitas dan kualitas yang telah dihasilkan dan sejauh mana pengawasan dilakukan.

2. Pengetahuan pekerjaan yaitu tingkat pengetahuan yang berkaitan dengan tugas pekerjaan yang akan memberi pengaruh langsung terhadap kualitas maupun kuantitas dari hasil kerja.

3. Tingkat inisiatif, dalam melaksanakan tugas yang dikerjakan khususnya dalam hal menangani masalah - masalah yang timbul.

4. Kecekatan mental yaitu kecepatan dan kemampuan dalam menerima perintah kerja dan menyelesaikan dengan situasi kerja serta cara kerja yang ada.

5. Sikap merupakan semangat yang diberikan dalam melaksanakan pekerjaan serta sikap positif dalam melaksanakan tugas pekerjaan.

6. Disiplin waktu dan absensi yng dimaksud disini yaitu tingkat kehadiran dan tingkat ketepatan waktu.

\section{B. METODE PENEELITIAN}

Metode yang digunakan oleh peneliti adalah pendekatan metode penelitian kuantitatif melalui desain deskriptif, yaitu metode yang menjelaskan nilai suatu variabel dengan mengolah data-data yang ada kedalam suatu angka dan pada tahap analisis data menggunakan statistik deskriptif untuk membuktikan hipotesis yang telah ditentukan dapat terbukti atau tidak.

Tekhnik pengumpulan data yang seharusnya digunakan dan tepat, sehingga betul-betul didapat data yang valid dan realibel sesuai dengan judul model pengawasan terhadap prestasi kerja pegawai di Rumah Sakit Arifin Nu'mang Rappang. Tekhnik pengumpulan data yang akan digunakan dalam penelitian ini, yaitu Observasi, Wawancara, Kuisioner, Dan Studi Kepustakaan sedangkan Analisis regresi sederhana digunakan untuk memprediksi nilai koefisien regresi dari masing-masing variabel dalam penelitian, yakni prestasi kerja pegawai (variabel $Y$ ) jika tingkat pengawasan (variabel $\mathrm{X}$ ) akan dinaikkan atau diturunkan. Analisis regresi sederhana juga digunakan untuk mengetahui nilai thitung sebagai dasar pengujian hipotesis penelitian.

\section{HASIL DAN PEMBAHASAN}

2302-6960

e-ISSN 2716-165X

Hasil yang didapatkan dari penelitian tentang Model Pengawasan terhadap Prestasi Kerja Pegawai di Rumah Sakit Arifin Nu'mang Rappang

1. Hasil penelitian dari model pengawasan : a) Pengawasan dalam cara berpakaian yang dilakukan yang dilakukan oleh direktur terhadap pegawai $57,8 \%$. b) Pengawasan dalam kelengkapan atribut yang dilakukan oleh direktur terhadap pegawai 51,4\%. c) Pengawasan dalam ketepatan waktu yang dilakukan oleh direktur terhadap pegawai 55\%. d) Pengawasan yang dilakukan oleh Badan Kepegawaian Dearah kepada pegawai $52,4 \%$. e) Pengawasan pelayanan yang dilakukan oleh Komisi Akreditasi 60\%. f) Pengawasan kelengkapan berkas yang dilakukan oleh Komisi Akreditasi 59\%. g) Pengawasan sarana dan prasarana yang dilakukan oleh Komisi Akreditasi 53,6\%. h) Penilaian masyarakat dengan melakukan pengaduan langsung ke pegawai $49 \%$. i) Penilaian masyarakat mealui kotak saran $47,4 \%$. Berdasarkan dari uraian tersebut, maka disimpulkan bahwa model pengawasan di Rumah Sakit Arifin Nu'mang Rappang berada pada kategori jarang dengan persentase 53,95\%.

2. Hasil penelitian dari indikator prestasi kerja : a) Prosedur pendaftaran pasien yang tidak berbelit-belit 53,4\%. b) Pemeriksaan yang telah sesuai dengan prosedur pelayanan $63 \%$. c) Pengetahuan pegawai dalam memberikan pelayanan kesehatan $60 \%$. d) Kemampuan pegawai dalam menangani masalah yang timbul dalam pekerjaan $56,2 \%$. e) Penyelesaian pekerjaan dengan tepat sesuai dengan perintah atasan langsung 58\%. f) Semangat dalam melaksanakan pekerjaan $57,8 \%$. g) Pegawai yang datang tepat waktu 53,4\%. h) Pegawai yang pulang tepat waktu 53,4\%. Berdasarkan dari uraian tersebut, maka disimpulkan bahwa prestasi kerja pegawai di Rumah Sakit Arifin Nu'mang Rappang berada pada kategori jarang dengan persentase $56,9 \%$.

3. Hasil penelitian dari faktor-faktor yang memengaruhi pengawasan : a) Pengembangan mutu agar tidak mengalami kegagalan 7,1\%. b) Pelatihan pegawai yang dilakukan agar tidak mengalami kegagalan $6,82 \%$. c) Peningkatan keahlian direktur $7,5 \%$. d) 
Peningkatan keahlian pegawai $6,97 \%$. e) Mengenai kesalahan diagnosa $5,37 \%$. f) Kesalahan pemberian obat $4,8 \%$. g) Tindakan pegawai yang salah pasien $5,5 \%$. h) tanggung jawab direktur yang memberikan kekuasaan terhadap pegawai dalam melaksanakan pekerjaan $7,3 \%$. Berdasarkan dari uraian tersebut, maka disimpulkan bahwa faktor-faktor yang memengaruhi pengawasan di Rumah Sakit Arifin Nu'mang Rappang berada pada kategori jarang dengan persentase $51,36 \%$.

Model pengawasan yang pertama yaitu pengawasan internal. Pengawasan internal merupakan pengawasan yang dilakukan oleh seorang atasan terhadap bawahannya. Pengawasan yang dimaksud di sini yaitu pengawasan yang dilkukan oleh direktur terhadap pegawai di Rumah Sakit Arifin Nu'mang Rappang dalam hal cara berpakaian sebesar 57,8\%, kelengkapan atribut $51,4 \%$, Ketepatan waktu $55 \%$.

Model pengawasan yang kedua yaitu pengawasan eksternal. Pengawasan eksternal merupakan pengawasan yang dilakukan oleh pihak luar. Pengawasan yang dimaksud di sini yaitu pengawasan yang dilakukan oleh Badan Kepegawaian Daerah kepada pegawai yang ada di Rumah Sakit Arifin Nu'mang Rappang yang jumlah pesentasinya sebesar $52,4 \%$.

Model pengawasan yang ketiga yaitu pengawasan formal. pengawasan formal merupakan pengawasan yang dilakukan oleh pejabat resmi atau instansi yang bisa dilakukan dengan cara formal ataupun informal. Pengawasan yang dimaksud di sini yaitu pengawasan yang dilakukan oleh Komisi Akreditasi Rumah Sakit yang melakukan penilaian akreditasi di Rumah Sakit Arifin Nu'mang Rappang yang melakukan pengawasan pelayanan dengan jumlah persentase sebesar $60 \%$, pengawasan kelengkapan berkas $59 \%$, dan pengawasan sarana dan prasarana $53,6 \%$.

Model pengawasan yang keempat yaitu pengawasan informal. Pengawasan informal merupakan penilaian yang dilberikan baik secara langsung maupun tidak langsung oleh masyarakat atau konsumen. Pengawasan yang dimaksud di sini yaitu penilaian yang dilakukan oleh masyarakat dengan pengaduan langsung ke pegawai dengan jumlah persentase sebesar 49\%, dan penilaian masyarakat melalui kotak saran sebesar $47,4 \%$.

Prestasi kerja yang pertama yaitu hasil kerja. Hasil kerja adalah tingkat kuantitas dan kualitas yang telah dihasilkan dan sejauh mana pengawasan dilakukan. Hasil kerja yang dimaksud di sini yaitu prosedur pendaftaran pasien yang berbeli-belit dengan persentase $53,4 \%$ dan pemeriksaan yang telah sesuai dengan prosedur pelayanan $63 \%$. Indikator prestasi kerja yang kedua yaitu pengetahuan pekerjaan. Pengetahuan pekerjaan yaitu tingkat pengetahuan yang berkaitan dengan tugas pekerjaan yang akan memberi pengaruh langsung terhadap kualitas maupun kuantitas dari hasil kerja. Pengetahuan yang dimaksud di sini yaitu pengetahuan pegawai dalam memberikan pelayanan kesehatan dengan persentase $60 \%$. Indikator prestasi kerja yang ketiga yaitu tingkat inisiatif. Tingkat inisiatif dalam melaksanakan tugas yang dikerjakan khususnya dalam hal menangani masalah masalah yang timbul. Tingkat inisiatif yang dimaksud di sini yaitu kemampuan pegawai menangani masalah yang timbul dalam pekerjaan dengan persentase $56,2 \%$.

Prestasi kerja yang keempat yaitu kecekatan mental. Kecekatan mental yaitu kecepatan dan kemampuan dalam menerima perintah kerja dan menyelesaikan dengan situasi kerja serta cara kerja yang ada. Kecekatan mental yang dimaksud di sini yaitu kemampuan dan kecepatan dalam menerima perintah dari atasan langsung dan menyelesaikan pekerjaan dengan persentase $58 \%$. Indikator prestasi kerja yang kelima yaitu sikap. Sikap merupakan semangat yang diberikan dalam melaksanakan pekerjaan serta sikap positif dalam melaksanakan tugas pekerjaan. Sikap yang dimaksud disini yaitu semangat dalam melaksanakan pekerjaan dengn persentase $57,8 \%$. Indikator yang keenam yaitun disiplin. Disiplin waktu dan absensi yaitu tingkat kehadiran dan tingkat ketepatan waktu. Disiplin yang dimaksud di sini yaitu pegawai yang datang tepat waktu dengan persentase $53,4 \%$ dan pegawai yang pulang tepat waktu dengan persentase yang sama yaitu $53,4 \%$.

Faktor yang pertama yaitu perubahan lingkungan organisasi. Melalui fungsi pengawasan yang memungkinkan manajer mendeteksi perubahan yang memberi pengaruh terhadap barang dan jasa organisasi, sehingga dapat menghadapi tentang memanfaatkan kesempatan yang 
diciptakan perubahan - perubahan yang terjadi. Perubahan lingkungan organisasi yang dimaksud di sini yaitu upaya untuk mengembangkan mutu agar tidak mengalami kegagalan dengan persentase $7,1 \%$ dan pelatihan agar tidak mengalami kegagalan dengan persentase $6,82 \%$. kedua yaitu peningkatan kompleksitas organisasi. Semakin besar organisasi maka semakin memerlukan pengawasan yang lebih hati-hati dan formal. Peningkatan kompleksitas organisasi yang dimaksud di sini yaitu peningkatan keahlian yang ada di Rumah Sakit Arifin Nu'mang Rappang yaitu peningkatan keahlian direktur dengan persentase $7,5 \%$ dan peningkatan keahlian pegawai $6,97 \%$. ketiga yaitu kesalahankesalahan. Kesalah-kesalahan sistem pengawasan yang memungkinkan manajer atau seorang pemimpin untuk menemukan kesalahan-kesalahan yang ada sebelum menjadi lebih buruk. Kesalahan-kesalahan yang dimaksud di sini yaitu kesalahan diagnosa dengan persentase $5,37 \%$, kesalahan pemberian obat 4,8\% dan tindakan pegawai yang salah pasien $5,5 \%$. keempat yaitu kebutuhan manajer untuk untuk mendelegasikan wewenang yaitu tanggung jawab atasan tidak berkurang bilamana manajer mendelegasikan wewenang kepada bawahannya. Kebutuhan manajer untuk mendelegasikan wewenang yang dimaksud di sini yaitu tanggung jawab direktur yang memberikan kekuasaan terhadap pegawai dalam melaksanakan pekerjaan dengan persentase $7,3 \%$.

Hasil dari uji Model Summary, pada bagian ini ditampilkan nilai $\mathrm{R}=0,545$ dan koefisien Determinasi Rsquare atau $\left(\mathrm{R}^{2}\right)$ sebesar 0.298 (adalah hasil pengkuadratan dari koefisien korelasi, atau 0,545 $\times 0,545=$ $0,298 \times 100 \%=29,8 \%)$, sedangkan sisanya $(100 \%-29,8 \%=70,2 \%)$. Hal ini menunjukkan pengertian bahwa untuk mencari besar faktor Pengawasan (X) terhadap Prestasi Kerja $(Y)$ dengan ini nilai yang dicari yaitu $29,8 \%$.

Hasil dari uji ANOVA pada bagian ini ditampilkan hasil yang diperoleh adalah nilai $\mathrm{F}=26,263$ dengan tingkat probabilitas sig. 0,000 . Oleh karena probabilitas $(0,000)$ jauh lebih keci dari 0,05, maka model regresi bisa dipakai untuk memprediksi Model Pengawasan. Untuk menguji kebenaran hipotesis dalam penelitian ini dilakukan uji $F$. Untuk mengetahui bahwa
pengaruh/Signifikan dapat diketahui dengan melihat dari lefel of signifikan $a=0,05$. Jika nilai signifikan lebih kecil dari 0,05, maka $\mathrm{HO}$ ditolak dan $\mathrm{Ha}$ diterima. Berdasarkan hasil olah pada tabel ANOVA, maka diketahui nilai Fhitung yang diperoleh sebesar 26,263 dengan tingkat signifikan 0,000 (Sig < 0,05) yang berarti bahwa variabel Model Pengawasan (X) mempunyai pengaruh/signifikan terhadap Prestasi Kerja $(Y)$, dari hasil tersebut berarti model regresi dapat digunakan untuk memprediksi Prestasi Kerja di Rumah Sakit Arifin Nu'man Rappang.

Berdasarkan uji Coefficients hasil olah data, maka model regresi yang akan digunakan dalam penelitian ini untuk mengukur pengaruh model pengawasan terhadap prestasi kerja pegawai di Rumah Sakit Arifin Nu'man Rappang.

Dari fungsi regresi di atas, maka dapat dijelaskan :

1. Jika variabel Model Pengawasan (X) berubah, maka Prestasi Kerja (Y) juga akan berubah. Tanda positif menunjukkan perubahan yang searah. Apabila Model Pengawasan meningkat, maka Prestasi Kerja juga dapat meningkat dengan koefisien regresi sebesar 0,464 dan sebaliknya, jika Model Pengawasan menurun, maka Prestasi Kerja juga dapat akan menurun dengan koefisien regresi sebesar 0,464.

2. Nilai konstanta sebesar 11,191 menunjukkan bahwa, jika semua variabel konstan maka Model Pengawasan masih bersifat positif.

Uji statistic $t$ untuk menunjukkan seberapa jauh pengaruh satu variabel penjela/independen secara individual menerangkan variasi variabel dependen berdasarkan tabel coefficients hasil olah data SPSS, maka diketahui bahwa :

1. Nilai thitung variabel Model Pengawasan (X) 5,125 dengan tingkat signifikan 0,000 .

2. Hipotesis berdasarkan uji t dirumuskan secara statistic

$$
\begin{aligned}
& \text { Ha: Pyx } \neq 0 \\
& \text { HO : Pyx } \neq 0
\end{aligned}
$$

\section{Hipotesis bentuk kalimat :}

1. $\mathrm{Ha}$ : Model pengawasan berpengaruh/signifikan terhadap prestasi kerja pegawai di Rumah Sakit Arifin Nu'mang Rappang. 
2. $\mathrm{HO}$ : Model pengawasan tidak berpengaruh/signifikan terhadap prestasi kerja pegawai di Rumah Sakit Arifin Nu'mang Rappang.

Kaidah Keputusan :

1. Jika nilai $t$ hitung $\geq t$ tabel, maka $\mathrm{HO}$ ditolak dan $\mathrm{Ha}$ diterima, artinya Signifikan

2. Jika nilai $t$ hitung $\leq t$ tabel, maka $\mathrm{HO}$ diterima dan $\mathrm{Ha}$ ditolak, artinya tidak Signifikan

Tabel Coefficients diperoleh $\mathrm{t}$ hitung $=$ 5,125 prosedur mencari statistic tabel dengan kriteria

1. Tingkat signifikan $(a=0,05)$

2. $\mathrm{df}=$ Jumlah Responden -2 atau $64-2=$ 62

$$
\text { 3. } \begin{aligned}
\mathrm{t} \text { tabel } & =\mathrm{a} / 2 ; \mathrm{df} \\
& =0,05 / 2 ; \mathrm{df} \\
& =0,025 ; 62
\end{aligned}
$$

Sehingga $\mathrm{t}$ tabel $=1,998$

Keputusan

Ternyata nilai $\mathrm{t}$ hitung $>\mathrm{t}$ tabel atau $5,125>1,998$, maka $\mathrm{HO}$ ditolak dan $\mathrm{Ha}$ diterima, artinya signifikan. Jadi, Model Pengawasan berpengaruh/signifikan terhadap Prestasi Keja Pegawai di Rumah Sakit Arifin Nu'man Rappang.

\section{KESIMPULAN}

Berdasarkan dari pembahasan sebelumnya maka hal ini dapat disimpulkan sebagai berikut:

1. Berdasarkan hasil penelitian dari model pengawasan, maka disimpulkan bahwa model pengawasan di Rumah Sakit Arifin Nu'mang Rappang berada pada kategori jarang dengan persentase $53,95 \%$.

2. Berdasarkan hasil penelitian dari indikator prestasi kerja, maka disimpulkan bahwa prestasi kerja pegawai di Rumah Sakit Arifin Nu'mang Rappang berada pada kategori jarang dengan persentase $56,9 \%$.

3. Berdasarkan hasil penelitian dari faktorfaktor yang memengaruhi pengawasan, maka disimpulkan bahwa faktor-faktor yang memengaruhi pengawasan di Rumah Sakit Arifin Nu'mang Rappang berada pada kategori jarang dengan persentase $51,36 \%$.

4. Berdasarkan hasil penelitian dan pembahasan nilai keseluruhan untuk pengaruh model pengawasan terhadap prestasi kerja pegawai di Rumah Sakit Arifin Nu'mang Rappang dinyatakan berpengaruh/signifikan.

\section{E. DAFTAR PUSTAKA}

Akhmad, I., Mustanir, A., \& Ramadhan, M. R. (2018). Pengaruh Pemanfaatan Tekhnologi Informasi dan Pengawasan Keuangan Daerah Terhadap Kualitas Laporan Keuangan Kabupaten Enrekang.

Baihaqi. (2016). Pengawasan Sebagai Fungsi Manajemen Perpustakaan Dan Hubungannya Dengan Disiplin Pustakawan. 8, 129-142.

Baron \& Byrne 1994 Social Psychology : Understanding Human Interaction. USA: Needham Heights Allyn \& Bacon Inc.

Dewi, R. (2013). Pengembangan Menajemen Dalam Meningkatkan Prestasi Kerja Pegawai Pada Balai Pelatihan Kesehatan Provinsi Sumatera Utara. Sumatera Utara 1(1), 21-26.

Glendoh, S. H. (2000). Fungsi Pengawasan dalam Penyelenggaraan Manajemen Korporasi. 2, 43-56.

Hamdi, M. (2016). Pengaruh Tingkat Pengawasan terhadap Kinerja Pegawai di Dinas Tenaga Kerja dan Transmigrasi Provinsi Banten Tahun 2016. Serang.

Hasibuan, S.P Malayu (2005). Manajemen Sumber Daya Manusia. Edisi Revisi. Jakarta : Bumi Aksara

Hesti Suprihatiningrum, T. B. (2011). Faktor Faktor Yang Mempengaruhi Prestasi Kerja ( Studi Pada Karyawan Kantor Kementrian Agama Provinsi Jawa Tengah ). Sekolah Tinggi Ilmu Ekonomi Widya Manggala, Semarang. 1-23.

Juari, P., \& Johannes, A. (2018). Analisis Penilaian Prestasi Kerja Pegawai Negeri Sipil di Badan Kepegawaian dan Pengembangan Sumber Daya Manusia Kabupaten Bulungan Provinsi Kalimantan Utara. Kalimantan Utara. III(1), 67-84.

Kamaruddin Sellang, M. D. (2014). Pengaruh Motivasi Kerja Terhadap Peningkatan Kinerja Aparatur Sipil Negara di Kantor Kelurahan Manisa Kecamatan Baranti 
Kabupaten Sidenreng Rappang Profinsi Sulawesi Selatan. (2), 111-120.

Latman, H., Iqbal, M., Al, S., \& Ahmad, J. (n.d.). Pengaruh Pengawasan Terhadap Efektivitas Penerimaan Retribusi Parkir pada Dinas Perhubungan, Komunikasi Dan Informatika Kabupaten Enrekang. $1-10$.

Baihaqi. (2016). Pengawasan Sebagai Fungsi Manajemen Perpustakaan Dan Hubungannya Dengan Disiplin Pustakawan. UPT Perpustakaan Universitas Syiah, Kuala Banda Aceh 8, 129-142.

Baron \& Byrne 1994 Social Psychology : Understanding Human Interaction. USA: Needham Heights Allyn \& Bacon Inc.

Dewi, R. (2013). Pengembangan Menajemen Dalam Meningkatkan Prestasi Kerja Pegawai Pada Balai Pelatihan Kesehatan Provinsi Sumatera Utara. Sumatera Utara 1(1), 21-26.

Glendoh, S. H. (2000). Fungsi Pengawasan dalam Penyelenggaraan Manajemen Korporasi. Universitas Kristen Petra 2, 43-56.

Hamdi, M. (2016). Pengaruh Tingkat Pengawasan terhadap Kinerja Pegawai di Dinas Tenaga Kerja dan Transmigrasi Provinsi Banten Tahun 2016. Serang.

Hasibuan, S.P Malayu (2005). Manajemen Sumber Daya Manusia. Edisi Revisi. Jakarta : Bumi Aksara

Hesti Suprihatiningrum, T. B. (2011). Faktor Faktor Yang Mempengaruhi Prestasi Kerja ( Studi Pada Karyawan Kantor Kementrian Agama Provinsi Jawa Tengah ). Sekolah Tinggi IImu Ekonomi Widya Manggala, Semarang. 1-23.

Juari, P., \& Johannes, A. (2018). Analisis Penilaian Prestasi Kerja Pegawai Negeri Sipil di Badan Kepegawaian dan Pengembangan Sumber Daya Manusia Kabupaten Bulungan Provinsi Kalimantan Utara. Kalimantan Utara. III(1), 67-84.
Marnis, P. (2014). Mananjemen Sumber Daya Manusia. Jl. Taman Pondok Jati J 3, Taman Sidoarjo.

Montolalu, T. Y. J., \& Kaparang, S. G. (2015). Pengaruh Motivasi Terhadap Prestasi Kerja Karyawan Studi Pada PT Pos Indonesia Tipe C Manado. Manado. 17.

Parhusip, C. M. D., \& Nurtjahjono, M. A. M. G. E. (2014). Pengaruh Disiplin Kerja terhadap Prestasi Kerja (Studi Pada Karyawan AJB BUMIPUTERA 1912 Cabang Kayutangan Kota Malang). Fakultas IImu Administrasi Universitas Brawijaya, Malang 9(1), 1-10.

Priyono. (2014). Manajemen Sumber Daya Manusia. Jl. Taman Pondok Jati J 3, Taman Sidoarjo

Samsirin. (2006). Konsep Manajemen Pengawasan dalam Pendidikan Islam. Universitas Darussalam Gontor.

Sugiyono. (2017). Metode Penelitian Kuantitatif Kualitatif Dan R\&D. Alfabeta, Bandung

Widena, K. S. (2018). Pengaruh Kompensasi Karyawan Terhadap Prestasi Kerja Karyawan Dengan Dimediasi Variabel Motivasi Kerja Karyawan. Fakultas IImu Administrasi, Universitas Brawijaya Malang. 61(1).

Widyawaty, M. (2015). Pengaruh Pelatihan Terhadap Prestasi Kerja Pegawai Pada Inspektorat Kabupaten Rokan Hulu. Fakultas Ekonomi, Universitas Pasir Pengaraian.

Yuniastuti, R. M. (2011). Pengaruh Kepuasan Kerja Terhadap Prestasi Kerja Karyawan Pada CV . Organik Agro System Di Bandar Lampung. Labuhan Ratu, Bandar Lampung 1, 199-210.

UU No 46 Tahun 2011 tentang Penilaian Presasi Kerja Pegawai Negeri Sipil. (2011). (2). 